Uşak Üniversitesi Sosyal Bilimler Dergisi

$2015,8 / 2$

\title{
İlköğretim Kurumu Öğrencilerinin Devamsızlık ve Okul Terki Nedenleri
}

\author{
Cemal AKÜZÜM* \\ Tuba YAVAŞ*+ \\ Çetin TAN ${ }^{* *+4}$
}

M. Berat UÇAR****

\section{Öz}

$\mathrm{Bu}$ araştırma, yönetici ve öğretmen görüşlerine göre, ilköğretim kurumu öğrencilerinin devamsızlık ve okul terki nedenlerini ortaya koymak ve okul mensuplarının bu nedenleri ortadan kaldırmaya yönelik uyguladıkları stratejileri saptamak amacıyla yapılan nitel bir çalışmadır. Araştırmanın çalışma grubunu, Zirve Üniversitesi ve Dicle Üniversitesi Sosyal Bilimler Enstitüleri Ortak Eğitim Bilimleri Eğitim Yönetimi, Teftişi, Planlaması ve Ekonomisi Ana Bilim Dalı Yüksek Lisans Programında öğrenim gören 30 okul yöneticisi ve 30 ilköğretim kurumu öğretmeni olmak üzere toplam 60 yönetici ve öğretmen oluşturmaktadır. Yönetici ve öğretmenlerin görüşleri, görüşme yöntemi aracıllı̆̆ı ile alınmıştır. Elde edilen veriler, nitel veri analizi tekniğinden yararlanılarak çözümlenmiştir. Araştırma bulguları, öğrencilerin devamsızlık ve okul terki davranışlarının kaynağının büyük oranda ailelerin çocuklarına karşı duyarlı olamayışları ve bu ailelerin karşılaştıkları ekonomik zorluklar ile okullardaki olanakların yetersizliği olduğunu göstermiştir. Eğitimcilerin devamsızlık ve okul terkini azaltmaya yönelik uyguladıkları stratejilerin ise, öğrenci velisi ile görüşme,

* Bu çalışmanın ilk taslağı, 22-24 Mayıs 2014 tarihinde Siirt Üniversitesi'nde düzenlenen Bilimin Işığında Eğitimsel Liderlik Üzerine Uluslararası Konferans'inda sözlü bildiri olarak sunulmuştur.

** Yrd. Doç. Dr., Dicle Üniversitesi Ziya Gökalp Eğitim Fakültesi, İlköğretim Bölümü, cemal.akuzum@dicle.edu.tr

*** Yrd. Doç. Dr., Mustafa Kemal Üniversitesi Eğitim Fakültesi, Eğitim Bilimleri Bölümü, tuubayavas23@gmail.com

****** Yrd. Doç. Dr., Siirt Üniversitesi Eğitim Fakültesi, Eğitim Bilimleri Bölümü, cettan889@hotmail.com

****** Arş. Gör., Dicle Üniversitesi Ziya Gökalp Eğitim Fakültesi, İlköğretim Bölümü, mberatu@gmail.com 
öğrenciye daha fazla ilgi gösterme ve sorumluluk verme şeklindeki bireysel çabalardan ibaret olduğunu göstermiştir. Elde edilen sonuçlar eşliğinde birtakım önerilere yer verilmiştir. Okul Terki.

Anahtar Kelimeler: İlköğretim Kurumu, Öğrenci, Devamsızlık,

\section{Reasons of School Absenteeism and Dropout of Primary School Students}

\section{Abstract}

This qualitative study aimed to determine the reasons of primary school students' absenteeism and dropout as well as what strategies school teachers and administrators use to eliminate those reasons. The study group was constituted a total of sixty participants, specifically thirty school administrators and thirty primary school teachers, who enrolled in Zirve University and Dicle University Social Sciences Institutes Common Educational Administration, Supervision, Planning and Economics M.S. Program. The opinions of administrators and teachers who participated in the study were gathered through interviews. Data obtained was analyzed by utilizing qualitative data analysis technique. According to findings of this study, the reasons of students' absenteeism and dropout were mostly resulted from families' insensitiveness to their children, economic handicaps of families, and incapable school facilities. In terms of strategies that administrators and teachers implement to diminish students' absenteeism and dropout, participants generally performed individual efforts such as getting contact with student' parents (guardian), devoting close attention to them, and giving responsibility. Finally, some recommendations were presented in the light of the results achieved.

Key Words: Primary School, Student, Absenteeism, Dropout.

\section{Giriș}

Bir ülkenin ekonomik, sosyal, bilimsel ve siyasi alanlarda gelişimi o ülkenin eğitim kalitesiyle oldukça yakından ilişkilidir (Lockheed ve Verspoor, 1991). Genç nüfusun ağırlıklı olduğu Türkiye'de bireylerin aldıkları ve alacakları eğitimin niceliği ve niteliği, dünya ülkeleriyle rekabet edebilecek yetkinliğe sahip donanımlı bir nesil yetiştirmede kilit rol oynamaktadır. Küçük yaşlardan itibaren ve üstelik zorunlu olarak verilen eğitim hizmetinin yürütüldügü okullar bu nedenle sıkça araştırma konusu olmuş bir parametredir. Bunun sebebi, aile dışındaki sosyal ortamlar olarak öğrenmenin en çok gerçekleşeceği yerlerin okullar olmasıdır. Böylece birey 
için okul hayatına başlamak önemli bir dönüm noktası olarak kabul edilmektedir (Oktay, 2007). Öğrencilerin, okullarıyla ilgili olumlu ve olumsuz tüm tecrübeleri, yaşantıları, tutum ve davranışları eğitimin kalitesinin tespitinde ve nasıl daha iyi hale getirilebileceği noktasında pek çok fikir verebilmektedir. Bu duruma örnek oluşturan faktörlerden birisi de öğrencilerin okullarına devam durumlarının incelenmesidir.

Ulusal ve uluslararası yazında devamsızlık ve okul terki kavramlarının tanımları kesin çizgilerle belirtilmemekle birlikte bu konuda farklı görüşler mevcuttur. Genel anlamda, öğrencilerin okula aralıklı gelme veya uzun süreli gelmeme durumları devamsızlık (school absence) olarak adlandırılmaktadır. Eğer bu durum çeşitli sebeplerden dolayı bir öğrencinin okulu bırakması veya eğitim sürecine devam etmeme kararı almış olması şeklinde kullanılırsa okul terki "dropout" olarak isimlendirilmektedir. Türkiye'deki tanımlamalara bakılırsa, öğrencilerin devam durumlarının işlendiği e-okul sisteminde iki devamsızlık tanımı mevcuttur. Bunlar; derslere ara sıra katılamayan ancak okula devam etmekte olan öğrenciler için kullanılan aktif devamsızlık; ve birtakım sebeplerden ötürü okula hiç devam etmeyen fakat kayıtları da silinmeyen öğrenciler için kullanılan pasif devamsızlık kavramlarıdır (MEB, 2009). Ancak bu kavramlar alan yazın için bağlayıcılığı olmayan ve sadece e-okul sisteminde kullanılan tanımlar olarak kalmiştır.

Bir öğrencide devamsızlık durumu kronikleşmeye başlayınca bunun daha sonra okulu tümden bırakma eylemine dönüşmesine sıkça rastlanmaktadır. Hatta bu durumun çoğu zaman uzun vadede işsiz, evsiz, yoksulluk çeken bireyler olmasina neden olduğu görülmüştür (House of Representatives, 1996). Bunun yanı sıra bireylerin eğitimleri için ayrılan kaynakların boşa gitmesine ve hatta herhangi bir eğitim kurumuna devam etmeyen ve bir iş sahibi olamayan kimi bireylerin işledikleri suçları önlemek için sarf edilen güvenlik masrafları ülkelere ciddi anlamda mali kayıplar yaşatmaktadır (Christenson vd., 2000). Daha somut bir örnek vermek gerekirse, sadece 2010 yılında Amerika Birleşik Devletlerindeki liseleri bırakan kişilerin tüm yaşamları boyunca alabilecekleri potansiyel maaşlarını (lost wages) alamayacak oluşlarının ülkeye getireceği mali kaybın yaklaşık 337 milyar dolar olacağı öngörülmüsstür (Alliance for Excellent Education, 2008). Bu tür bir giderin olmasının sebebi, söz konusu kişilerin daha az geliri olan işlerde çalışarak hatta belki iş bile bulamayarak ülkenin ekonomisine daha az katkı sağlamalarına, bundan dolayı ülkede sosyal hizmetin sunulabilmesi için tüm yurttaşlardan daha fazla vergi alınmasının gerekecek olmasıdır (Campell, 2003). Öte yandan, okulu bırakmış kişilerin psikolojik rahatsızlıklar gösterme (Fortin vd., 2006) ve çeşitli suçlardan dolayı hüküm 
giyme (Cassel, 2003; Walters, 1992) eğiliminde oldukları tespit edilmiştir. Ayrıca, devamsızlık yapmanın akademik başarıyı olumsuz yönde etkilediği de bilinen bir durumdur (Eastman, 1998; Eğitim Reformu Girişimi, 2009). Okul devamsızlıklarının ve terklerinin böylesine büyük sorunlar açıyor olması, bu sorunun nedenlerinin irdelenmesi ve çözüm arayışlarının aranması ihtiyacını doğurmaktadır.

Öğrencileri okula devam etmemeye ve okulu tümden terk etme durumlarına iten nedenleri irdeleyen pek çok araştırma mevcuttur. Yükseköğretim basamağındaki okul terkleri genellikle maddi sıkıntılar ve akademik olarak uyum sağlayamama (Bülbül, 2012) gibi nedenlerden kaynaklanırken, daha alt kademelerdeki sebepler çeşitlenmektedir. Bu çalışmanın amacı doğrultusunda özellikle ilköğretim kademesindeki okul devamsızlıkları ve terkleri ile ilgili çalışmalar incelenmiştir.

Okula devam etmeme davranışlarına neden olan faktörler incelendiğinde, önceki araştırma sonuçları okul terkinin genellikle bireysel, ailesel-sosyal, ve okul ile alakalı faktörlerden kaynaklandığı görülmektedir. Devamsızlık yapmaya neden olan bireysel etmenlerin başında öğrencinin geçirdiği sağlık sorunları ve başarısız olma korkusu yer almaktadır (Tutar, 2002). Bununla beraber bazen öğrencinin ruhsal birtakım sıkıntılar nedeniyle okula gitmek istememesi bir başka deyişle okulu reddetmesi de devamsızlık ve okul terkiyle sonuçlanan bir durumdur (Bahalı ve Tahiroğlu, 2010). Ayrıca akademik anlamda başarısız öğrenciler arkadaşlarından geri kalarak bazen saygınlıklarının azalmasına neden oldukları için okulu terk etme eğilimine girebilmektedirler (Aydın, 2006). Yine ilkokul ve ortaokul kademelerinde yapılan bir araştırmaya göre, öğrencilerin okulu bırakmalarının en büyük sebepleri olarak okula ilgilerinin az olması ve okul masraflarının çok olması şeklinde tespit edilmiştir (hurriyet.com.tr, 2001).

Öğrencinin yetiştiği ailenin de öğrencilerin devamsızlık yapma eylemlerinde etkili olduğu görülmüştür. Çocuğu ile ilgilenen, okulla işbirliği halinde olan ebeveynlerin çocuklarının başarısının, güdülenmesinin ve düzenli devamının sağlanmasında etkili olduğu belirlenmiştir (Burns, 1993). Öte yandan, maddi sıkıntıları olan ailelerde çocukların eğitim ihtiyacına yeteri kadar cevap verilememesi ve hatta çocuğun da çalışmak zorunda olması okul devamsızlıklarına önemli ölçüde sebep olmaktadır (Diyu, 2001). Örneğin, ailelerin, çocuklarının okul yaşantılarına ilişkin ihtiyaçlarını karşılayamamaları ve yoksulluğun özgüven eksikliğine yol açarak öğrencilerin devamsızlık davranışları sergilemelerine en çok sebep olan faktörler olduğu belirlenmiştir (Özbaş, 2010; Yavuzer, 1996). Ailesel faktörlerin devamsızlık durumuna etkisine paralel olarak, öğrencinin arkadaş çevresi ve yaşadığı ortamdaki sosyal çevre de devamsızlık 
yapmasında rol oynayabilmektedir. Örneğin, arkadaş grubu başarısız, okula devamsızlık yapan veya hiç gitmeyen, madde bağımlısı, suç işlemekte olan kişiler olan öğrencilerin en çok risk altında olduğu belirtilmektedir (Özbaş, 2010). Yine Amerika Birleşik Devletleri Ulusal Okula Adaptasyon Merkezi'nin araştırmasına göre, öğrencinin etrafında olumsuz rol modellerin çokça bulunması ve eğitimin önemli olduğuna dair bir bakış açısı bulunmayan ortamda yaşaması, öğrenciyi devamsızlık ve okul terkine götüren sebeplerden bazılarıdır.

$\mathrm{Bu}$ alandaki çalışmalar, öğrencilerin devamsızlığa ve okul terkine iten nedenler arasında okul ve eğitim sisteminden kaynaklanan unsurların da olduğunu göstermiştir. Öğrencinin okula ve/veya öğretmenine karşı memnuniyetinin azalması onu okulu terk etme konusunda cesaretlendirmektedir (Şimşek, 2011; Reyes ve Jason, 1993). Öğrencilerin okuldan yeteri kadar destek bulamamaları, okul içinde kural dışı davranışların çokça yaşanması ve bundan mağdur olunması öğrencileri devamsızlık yapma ihtimallerini artırmaktadır (Şimşek ve Katıtaş, 2014). Ayrıca, Yıldız ve Kula'nın (2011) ortaokulda öğrenim gören 2600 öğrenciyle yaptıkları çalışmada, öğrencilerin seviye belirleme sınavına çalışmak için okula gelmemelerinin devamsızlık yapma gerekçelerinin başında olduğu ortaya çıkmıştır.

Yapılan çalışmalarda ayrıca cinsiyet farkının da okul devamsızlığı ve terkini etkileyip etkilemediği incelenmiştir. Her ne kadar devamsızlık ve okul terkleri her iki cinsiyette de görülse de Türkiye şartlarında erkeklerin daha fazla dersten kaçma, okula düzensiz gelme ve okulu bırakma davranışlarının kızlara oranla daha yüksek olduğu gözlenmiştir (Uysal ve Şahin, 2007; Şimşek ve Şahin, 2014). Fakat aksini gösteren raporlar da mevcuttur. Milli Eğitim Bakanlığı ve UNICEF'in Devamsızlık ve Okulu Terk Riski Durum Saptaması ve İhtiyaç Analizi Raporuna göre, pasif devamsızlık yapan kız öğrenciler örneklemin \%66,6'sını oluşturmuştur. Özellikler daha az gelişmiş şehirlerde bu oran bu şekilde çıkabilmektedir. Örneğin, Tunç (2009) çalışmasında, kızların okula gitmemelerinin altında yatan sebeplerin ekonomik sebepler, muhafazakâr ve ataerkil toplumsal yapı olduğu sonucuna varmıştır.

İlgili alan yazın taramasından anlaşıldığı gibi, okul devamsızlıkları ve terkleri bireysel, sosyal ve ekonomik açıdan topluma büyük sıkıntılar getirmektedir. Her ne kadar ilköğretim eğitimi devlet tarafından parasız ve zorunlu olarak veriliyor olsa da, tüm öğrencilerin okula devam etmedikleri bilinmektedir. Özellikle de buna rağmen ilköğretim kademelerinde devamsızlık ve terk nedenlerini irdeleyen çalışmalar sınırlı sayıdadır. Bundan dolayı bu kademedeki devamsızlıkların ve okul terklerinin önüne 
geçilebilmesi hayati önem taşımaktadır. Dolayısıyla bu çalışma yukarıda bahsedilen başlıklar dâhilinde devamsızlık ve okul terki sorununu detaylı olarak araştırmayı hedeflemiştir.

\section{Araştırmanın Amacı}

$\mathrm{Bu}$ araştırma, yönetici ve öğretmen görüşlerine göre, ilköğretim kurumu öğrencilerinin devamsızlık ve okul terki nedenlerini ortaya koymak ve okul mensuplarının bu nedenleri ortadan kaldırmaya yönelik uyguladıkları stratejileri saptamak amacıyla yapılmıştır.

$\mathrm{Bu}$ genel amaç çerçevesinde aşağıdaki sorulara yanıtlar aranmıştır:

1. Öğrencilerin devamsızlık ve okul terki nedenleri nelerdir?

2. Öğrencilerin devamsızlık ve okul terki eğilimlerinin anlaşılma durumu nedir?

3. Öğrencilerin devamsızlık ve okul terkinde okulun etkileri nelerdir?

4. Öğrencilerin devamsızlık ve okul terkinde ailenin etkileri nelerdir?

5. Öğrencilerin devamsızlık ve okul terkinde sosyal çevrenin etkileri nelerdir?

6. Öğrencilerin devamsızlık ve okul terkinde akademik başarı kaygisının etkileri nelerdir?

7. Yöneticilerin ve öğretmenlerin, öğrencilerin devamsızlık ve okul terkini azaltmaya yönelik uyguladıkları stratejiler nelerdir?

\section{Yöntem}

\section{Araştırma Modeli}

$\mathrm{Bu}$ çalışmada, nitel araştırma yaklaşımı kullanılmıştır. Nitel araştırmalar, üzerinde araştırma yapılan ya da yapılması planlanan kişilerin sahip oldukları deneyimlerinden doğan anlamların sistematik olarak incelenebilmesinde tercih edilen bir tekniktir (Ekiz, 2013). Nitel araştırma tekniklerinin doğal ortama duyarlılık sağlaması, araştırmacının katılımcı rolünün olması, bütüncül bir yaklaşıma sahip olması, algıların ortaya konmasını sağlaması, araştırma deseninde esnekliği olması ve tümevarımcı bir analize sahip olması önemli özellikleridir (Yıldırım ve Şimşek, 2008). Bu bağlamda nitel araştırmalar, araştırmanın üretildiği sosyal bağlama duyarlılığ1 sağlamakta (Kuş, 2003) ve gerçeği görmeye ve yorumlamaya olanak vermektedir (Rossman ve Rallis, 1998). 


\section{Çalışma Grubu}

Araştırmanın çalışma grubunu, Zirve Üniversitesi ve Dicle Üniversitesi Sosyal Bilimler Enstitüleri Ortak Eğitim Bilimleri Eğitim Yönetimi, Teftişi, Planlaması ve Ekonomisi Ana Bilim Dalı Yüksek Lisans Programında öğrenim gören 30 okul yöneticisi ve 30 ilköğretim kurumu öğretmeni olmak üzere toplam 60 yönetici ve öğretmen oluşturmaktadır. Çalışma grubu "kolay ulaşılabilir durum örneklemesi" yöntemiyle seçilmiştir. Bu yöntemde araştırmacı yakın ve erişilmesi kolay olan bir durumu seçmektedir (Yıldırım ve Şimşek, 2008). Tamamını ilköğretim kurumlarında görev yapan yöneticilerin ve öğretmenlerinin oluşturduğu çalışma grubunun \%23'ü ( $\mathrm{f}=14)$ kadın, \%77'si ( $\mathrm{f}=46)$ erkektir. Mesleki kıdem açısından katılımcıların \%33'ü (f=20) 10 yıldan az, \%50'si (f=30) 10-19 yıl arası ve \%17'si ( $\mathrm{f}=10)$ 20-29 yıl arası kıdeme sahiptir. Branşlarına göre, çalışma grubunun \%67'si ( $f=40)$ Sosyal Bilimler, \%30'u ( $\mathrm{f}=18)$ Fen-Matematik Bilimleri ve \%8'i (f=5) Güzel Sanatlar/Özel yetenek branşına sahiptir. Görev yaptıkları okuldaki çalışma sürelerine göre ise, öğretmen ve yöneticilerin $\% 65$ 'i (f=39) 5 yıl ve daha az, \%35'i (f=21) 6 yıl ve üzeri bir çalışma süresine sahiptir.

\section{Veri Toplama Aracı}

Veri toplama aracı olarak, formun nasıl doldurulacağına yönelik yönerge ile katılımcılara ait kişisel bilgilerin yer aldığı ve araştırmacılar tarafından geliştirilen "yarı yapılandırılmış görüşme formu" kullanılmıştır. Araştırmanın asıl verilerini toplamak amacıyla yarı yapılandırılmış görüşme formu uygulanmadan önce problem durumunun daha iyi anlaşılması, alanın tanınması ve araştırmaya yön vermesi amacıyla Zirve Üniversitesi ve Dicle Üniversitesi Sosyal Bilimler Enstitüleri Ortak Eğitim Bilimleri Eğitim Yönetimi alanında öğrenim gören yönetici ve öğretmenlerle araştırma konusu tartışılmış ve konuyu derinlemesine irdeleme olanağı sağlayabilecek görüssler not edilmiştir. Bu aşama araştırma sorularını oluşturma ve görüşme sorularını yapılandırma amacıyla kullanılmış bulgu olarak sunulmamıştır.

Yarı yapılandırılmış görüşme formu, çalışmanın amacına uygunluğu, açıklık ve anlaşılırlığı açısından bir alan bilgisi ve bir dil bilgisi uzmanın görüşüne sunulduktan sonra uygulama şeklini almıştır. Bu yöntemin takip edilmesiyle ölçme aracının kapsam ve görünüş geçerliği sağlanmaya çalışılmıştır. Çünkü Büyüköztürk (2007), bir ölçme aracının kapsam ve görünüş geçerliğinin uzman görüşleriyle değerlendirilebileceğini vurgulamaktadır. 


\section{Verilerin Analizi}

Görüşme yapılan kişilere yöneltilen sorulara alınan yanıtlar, betimlenerek içerik analizine tabi tutulmuş ve belirlenen temalar eşliğinde çözümlenmiş ve yorumlanmıştır. Verilerin çözümlenmesinde nitel veri analizi bilgisayar paket programından (NVivo 8) yararlanılmıştır. İçerik analizinde temelde yapılan işlem, birbirine benzeyen verileri belirli kavramlar ve temalar çerçevesinde bir araya getirmek ve bunları okuyucunun anlayacağı biçimde düzenleyerek yorumlamaktır (Yıldırım ve Şimşek, 2008). Öte yandan nitel içerik analizi; dilsel materyal ve metinlerin sistematik olarak analizine, materyallerin bölme ve aşamalı olarak incelenmesine, çözümleme boyutlarının materyalin kuramsal olarak kategorileştirilmesi yoluyla önceden belirlenmesine fırsat tanımaktadır (Mayring, 1996; Aktaran: Gümüş ve Durgun, 2000). Analiz sürecinde yöneticilerin ve öğretmenlerin, öğrencilerin devamsızlık ve okul terki nedenlerine, eğilimlerine ve bunu önlemeye yönelik uyguladıkları stratejilere ilişkin görüşleri çözümlenmiş ve ortaya çıkan temalar, aralarındaki bağları gösterir şekilde modellendirilmiştir.

Araştırmanın güvenirliğini sağlamak için, araştırmada ulaşılan 7 tema altında verilen görüşlerin söz konusu temaları temsil edip etmediğini teyit etmek amacıyla uzman görüşüne başvurulmuştur. Araştırmacıların ve uzmanın, temalarda yer alması gereken görüşlere ilişkin değerlendirmeleri karşılaştırılarak "görüş birliği" ve "görüş ayrıllı̆ı" sayıları tespit edilmiş ve Miles ve Huberman'ın (1994) formülü, "Güvenirlik = [Görüş birliği sayısı / (Toplam görüş birliği sayısı + Görüş ayrılığı] X 100" kullanılarak araştırmanın güvenirliği hesaplanmıştır. Kodlama şemasının büyüklüğüne ve aralığına bağlı olarak, uzman ve araştırmacı değerlendirmeleri arasındaki uyumun \%90 ve üzeri olduğu durumlarda arzu edilen düzeyde bir güvenirlik sağlanmış olmaktadır (Miles ve Huberman, 1994). Bu araştırmaya özgü olarak gerçekleştirilen güvenirlik çalışmasında \% 93 oranında bir uzlaşma (güvenirlik) sağlanmıştır.

\section{Bulgular}

İlköğretim kurumlarında öğrencilerin devamsızlık ve okul terki nedenlerine ilişkin yönetici ve öğretmen görüşleri yedi alt temada ele alınmıştır. Bu bölümde yönetici ve öğretmen görüşleri bu alt temalara göre verilmiştir. Yapılan doğrudan alıntıların kimlik belirtmemesi için katılımcı isimleri kodlanmış ve katılımcların gerçek isimleri gizli tutulmuştur. Katılımcılar, görüşme sırasına göre; Yönetici 1, Öğretmen 1, ... şeklinde gösterilmiştir. 


\section{A. Öğrencilerin Devamsızlık ve Okul Terki Nedenleri}

İlköğretim kurumlarında görev yapan yönetici ve öğretmenlerin, öğrencilerin devamsızlık ve okul terki nedenlerine ilişkin görüşlerini almak amacıyla "Sizce öğrencilerin devamsızlık yapmalarına veya okulu terk etmelerine neden olan faktörler nelerdir?" sorusu sorulmuştur. Şekil 1'de yönetici ve öğretmenlerin görüşleri doğrultusunda oluşturulan, öğrencilerin devamsızlık ve okul terki nedenlerine ilişkin temalar ile bu temalar altında yer alan alt temalar arasındaki ilişkiyi ve bu ilişkinin yönünü gösteren bir model yer almaktadir.

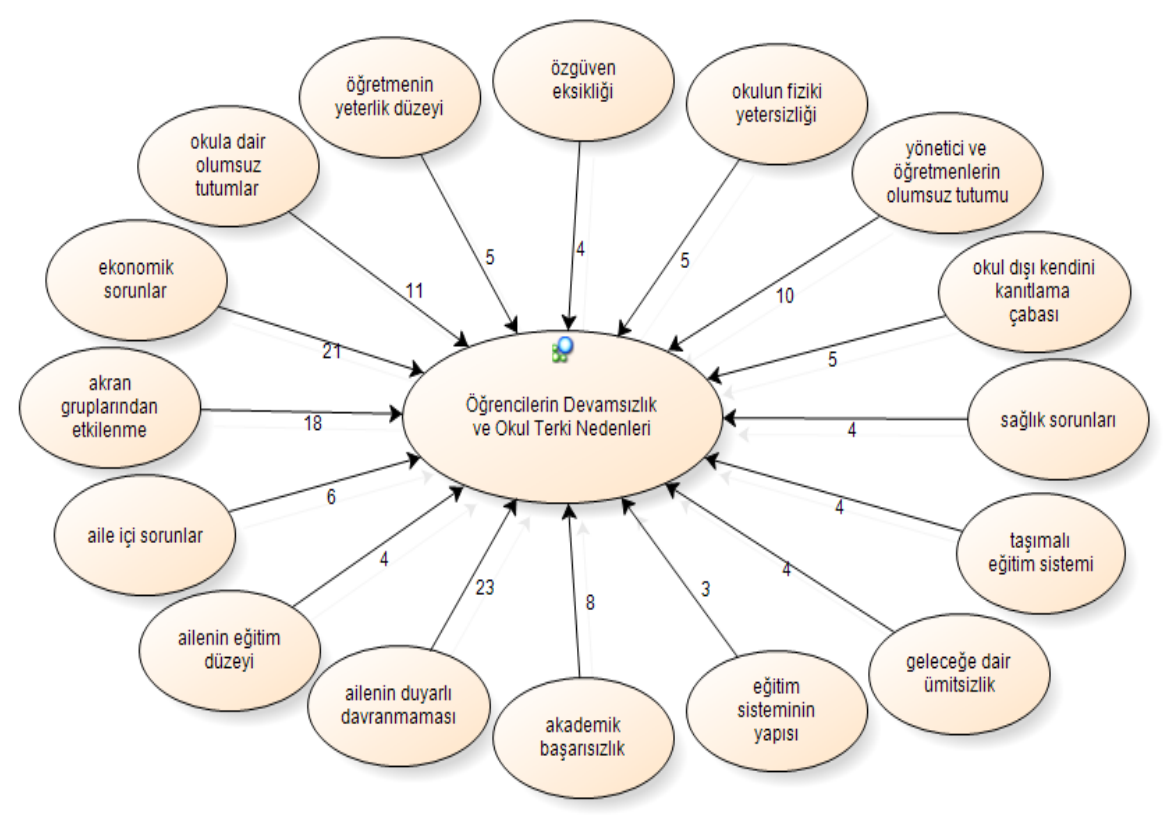

Şekil 1. Yönetici ve Öğretmenlerin, Öğrencilerin Devamsızlık ve Okul Terki Nedenlerine İlişkin Düşüncelerinden Oluşturulan Model

Şekil 1'de yönetici ve öğretmenlerin, öğrencilerin devamsızlık ve okul terki nedenlerine ilişkin görüşleri 16 alt temada kodlandığ 1 görülmektedir. Öğrenci devamsızlığ ailenin öğrencinin akademik gelişimi konusunda duyarlı davranmaması $(f=23)$, ailenin karşılaştığı ekonomik sorunlar $(f=21)$, öğrencinin akran gruplarından etkilenmesi $(f=18)$, öğrencinin dolayısıyla da ailenin okula dair olumsuz tutumları $(f=11)$ ve okul yöneticilerinin ve öğretmenlerinin öğrenciye karşı sergiledikleri olumsuz tutumların $(f=10)$ olduğu tespit 
edilmiştir. Diğer nedenler ise azalan bir sırada; akademik başarısızlık, aile içi sorunlar, öğretmenin yeterlik düzeyi, öğrencinin okul dışında kendini kanıtlama çabası, okulun fiziki yetersizliği, öğrencideki özgüven eksikliği, sağlık sorunları, geleceğe dair ümitsizlik içerisinde olması, ailedeki düşük eğitim seviyesi, taşımalı eğitim sistemi ve eğitim sisteminin yapısal sorunlarından kaynaklanan nedenlerin öğrencilerin devamsızlığa ve okulu bırakmalarına neden olduğu anlaşılmaktadır.

Bu konuyla ilgili katılımcıların görüşlerinden bazıları örnek olarak aşağıda verilmiştir:

"Okulun fiziksel anlamda cazibesinin olmaması, akademik başarı noktasında öğrenciye özgüven kazandırılmaması, öğretmen ve idarecilerin yoğunluklarından dolayı öğrencilere gerekli ilgiliyi gösterememeleri öğrenci devamsizliklarına hatta okul terkine neden olmaktadır (Öğretmen, 9)."

"Kırsal kesimde temel neden ailenin çocuğa yüklemiş olduğu tarlada çalı̧ma veya hayvanları otlatmaya gönderme gibi sorumluluklardır. İkinci bir husus, okullarımızın öğrencilerin ikamet etikleri yerleşim yerinden uzak olması yani taşımalı eğitim sisteminin yapılıyor olması, ayrıca eğitim bir ekmek kapısı olarak görüldü̆̆̈̈nden çocuk belli sinıflarda başarısız olduğunda "bundan bir şey çıkmaz" denip çocuk okuldan alınıp başka işlere gönderiliyor. Açık ilköğretim böyle düşününler için iyi bir neden oldu maalesef (Öğretmen, 21)."

\section{Anlaşılma Durumu \\ B. Öğrencilerin Devamsızlık ve Okul Terki Eğilimlerinin}

Yöneticilerin ve öğretmenlerin, öğrencilerin devamsızlık ve okul terki eğilimlerinin anlaşılma durumuna ilişkin görüşlerini almak amacıyla “Öğrencilerin devamsızlık ve okul terki eğiliminde olduğunu anlayabiliyor musunuz?" sorusu sorulmuştur. Şekil 2'de öğrencilerin devamsızlık ve okul terki eğilimlerinin anlaşılma durumuna ilişkin oluşturulan temalar ile bu temalar altında yer alan alt temalar arasındaki ilişkiyi ve bu ilişkinin yönünü gösteren bir model oluşturulmuştur.

Çalışmaya katılan öğretmen ve okul yöneticilerinin öğrencilerin devamsızlık ve okul terki eğiliminde olup olmadıklarını nasıl anladıklarına ilişkin yanıtları incelendiğinde, $52(\% 86,7)$ katılımcı bu eğilimde olan öğrencileri tespit edebildiklerini belirtirken, 8 (\%13,3) katılımcının ise "Hayır" yanıtını vererek tespit edemediklerini belirtmişlerdir. "Evet" yanıtını veren katılımcıların bu konudaki görüşleri 7 alt temada kodlanmıştır. Şekil 3'te de görüldüğü gibi, katılımcılar; öğrencilerin derse 
karşı ilgisiz olmalarından $(f=21)$, arkadaşlık kurdukları kişilerden $(f=17)$, disiplinsiz davranışlarından (arkadaşlarına şiddet uygulama, öğretmenlere karşı saygısızlık) $(f=16)$, okula ve derslere geç gelmelerinden $(f=15)$, akademik başarılarının düşük olmasından $(f=8)$, derslere girmemelerinden $(f=7)$ ve ödevlerini yapmamalarından $(f=6)$, öğrencilerin devamsızlık yapma veya okulu terk etme eğilimlerinin önemli göstergeleri olarak ifade etmektedirler.

Bu konuyla ilgili öğretmenlerin cevapları örnek olarak aşağıda verilmiştir:

"Evet, çünkü sürekli sinıfta huzursuzluk çıkaran, öğretmenlere karşı gelen ve okul arkadaşlarına şiddet uygulayan öğrencilerin büyük oranda ve yakm zamanda okuldan koptuklarmı gözlemlemekteyim (Öğretmen, 1)."

"Evet, derslerden soğuması, sınıf arkadaşlarıyla samimiyetinin azalması, okul dışında arkadaş çeoresinin artması, derslere geç girmeye başlaması, sinavlara girmemesi öğrencinin devamsızlı veya okulu terk etme eğiliminde olduğunu anlayabiliyorum (Öğretmen, 2)."

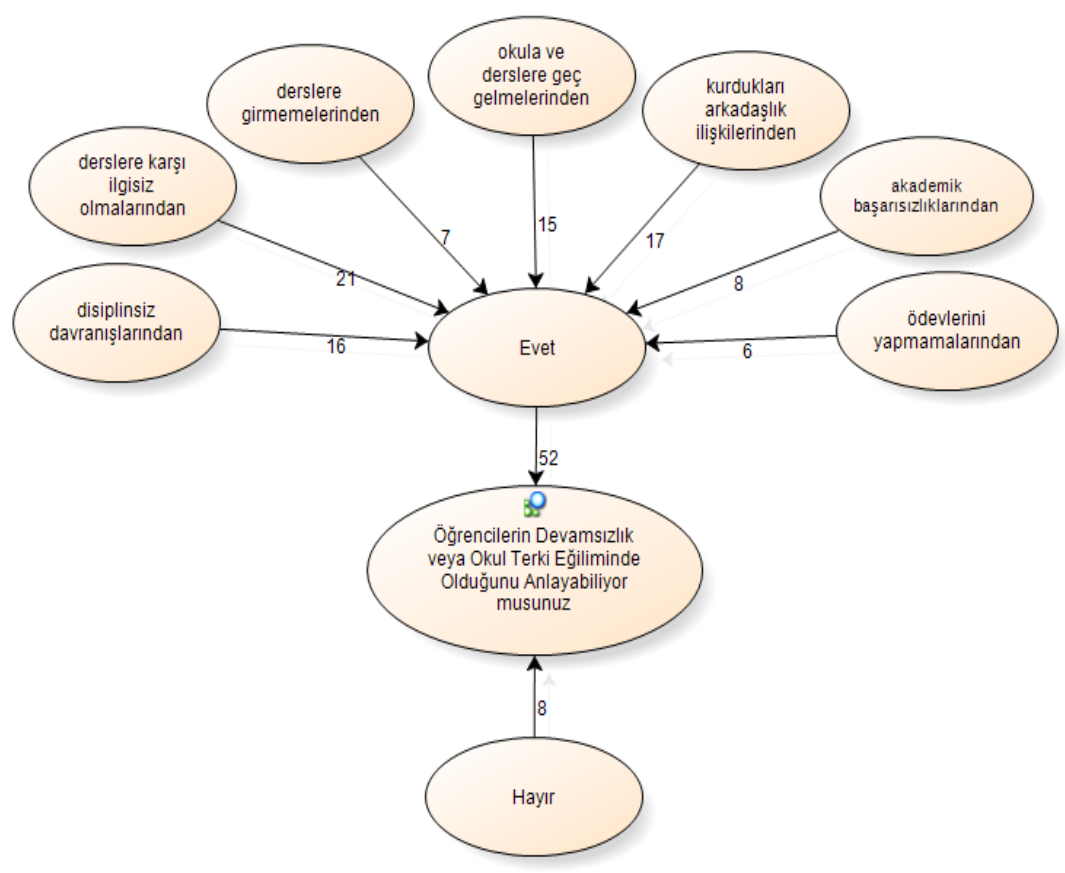

Şekil 2. Yönetici ve Öğretmenlerin, Öğrencilerin Devamsızlık ve Okul Terki Eğilimlerinin Anlaşılma Durumuna İlişkin Düşüncelerinden Oluşturulan Model 


\section{C. Öğrencilerin Devamsızlık ve Okul Terkinde Okulun Etkisi}

Yöneticilerin ve öğretmenlerin, öğrencilerin devamsızlık ve okul terkinde okulun etkilerine ilişkin görüşlerini almak amacıyla "Öğrencilerin devamsızlık ve okul terkinde okulun sorumlu olduğunu düşünüyor musunuz?" sorusu sorulmuştur. Şekil 3'te öğrencilerin devamsızlık ve okul terkinde okulun etkisine ilişkin oluşturulan temalar ile bu temalar altında yer alan alt temalar arasındaki ilişkiyi ve bu ilişkinin yönünü gösteren bir model oluşturulmuştur.

Şekil 3 incelendiğinde, öğrencilerin devamsızlık ve okul terkinde okulun sorumlu olduğunu 42 (\%70) katılımcı belirtirken 18'i (\%30) ise okulun bir sorumluluğu olmadığını düşündügünü ifade etmektedir. Okulun sorumluluğu olduğunu düşünen katılımcıların yanitları 6 alt temada kodlanmıştır. Bunlar; okulun öğrencilere karşı olumsuz tutumu (yöneticinin olumsuz tutumu, öğretmenin duyarlı davranmaması, öğrenciyi önemsememe, öğrenciyi desteklememe) $(f=20)$, okulun öğrencilerin ihtiyaçlarını karşılayamaması (fiziksel olanaklarının yetersizliği, eğitsel etkinliklerin az olması, sınıfların kalabalık olması) $(f=14)$, okul mensupları arasındaki iletişimsizlik $(f=4)$, ailelerle etkili iletilişim kurulmaması $(f=3)$, aşırı disiplin uygulamaları $(f=2)$ ve öğretmenlerin sık değişmesidir $(f=2)$. 


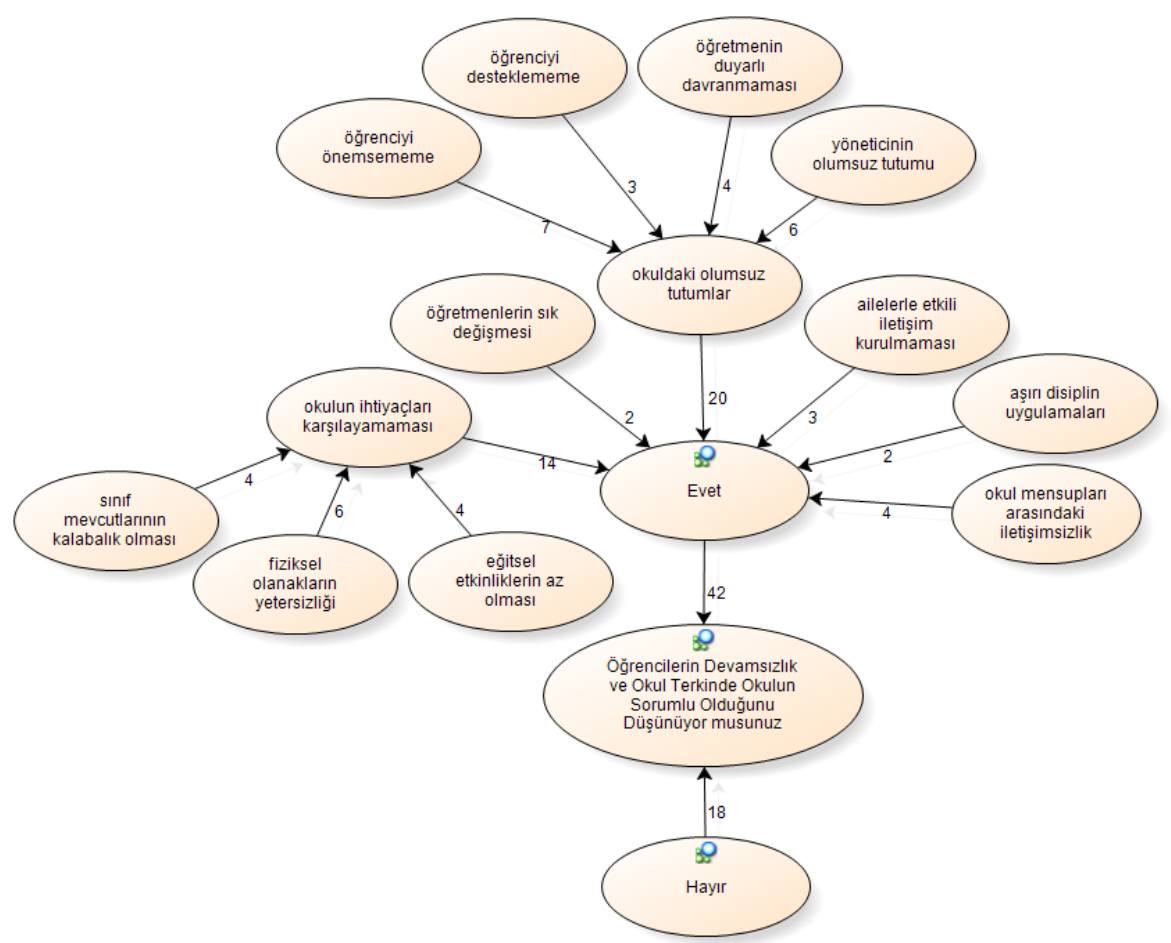

Şekil 3. Yönetici ve Öğretmenlerin, Öğrencilerin Devamsızlık ve Okul Terkinde Okulun Sorumluluklarına İlişkin Düşüncelerinden Oluşturulan Model

Bu konuyla ilgili öğretmenlerin cevapları örnek olarak aşağıda verilmiştir:

"Kesinlikle sorumlu olduğunu düşünüyorum. Öğrenci, kendisine hitap edecek yaşantı ve etkinlik alanını okulda bulamazsa, zamanla bu ihtiyaçlarını dış çevrelerden gidermeye çalışacak ve devamsizlık sorunlarına neden olacaktır (Öğretmen, 23)."

"Evet, etkisi vardır. Problemli ve devamsizlik yapma veya okulu terk etme riski taşıyan öğrencilerin yeterince desteklenmemesi ya da okul ortaminın veya şartlarmın yeterince elverişli olmaması, öğretmen ve idarecilerin olumsuz tutum ve davranışlar en önemli sebepler olarak görülebilir (Yönetici, 5)."

\section{D. Öğrencilerin Devamsızlık ve Okul Terkinde Ailenin Etkisi}

Yöneticilerin ve öğretmenlerin, öğrencilerin devamsızlık ve okul terkinde ailenin etkilerine ilişkin görüşlerini almak amacıyla "Öğrencilerin devamsızlık ve okul terkinde ailenin sorumlu olduğunu düşünüyor 
musunuz?" sorusu sorulmuştur. Şekil 4'te öğrencilerin devamsızlık ve okul terkinde ailenin etkisine ilişkin oluşturulan temalar ile bu temalar altında yer alan alt temalar arasındaki ilişkiyi ve bu ilişkinin yönünü gösteren bir model yer almaktadir.

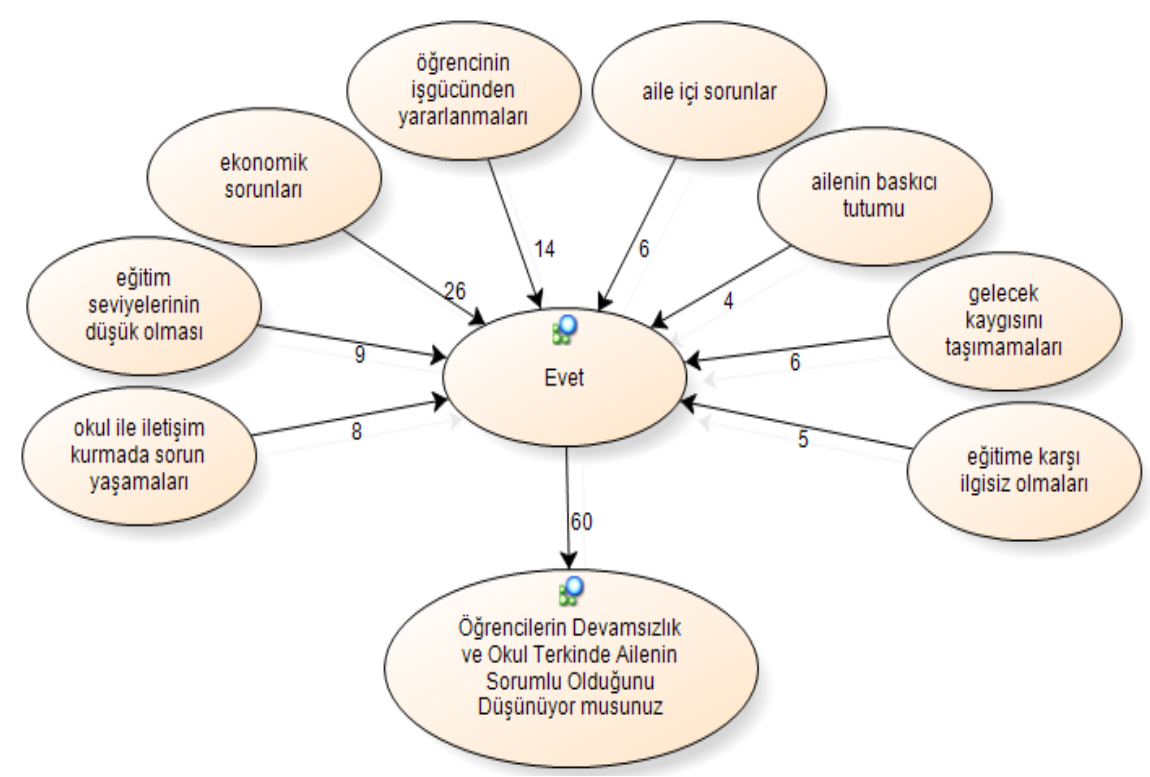

Şekil 4. Yönetici ve Öğretmenlerin, Öğrencilerin Devamsızlık ve Okul Terkinde Ailenin Sorumluluklarına İlişkin Düşüncelerinden Oluşturulan Model

Şekil 4'e göre, katılımcıların tamamı $(f=60, \% 100)$ öğrencilerin devamsızlık ve okul terkinde ailenin sorumlu olduğunu ifade etmektedir. Ailelerin sorumluluğunun nasıl olduğuna ilişkin yanıtları ise 8 alt temada kodlanmıştır. Öğretmenlere ve yöneticilere göre ailenin yol açtığ devamsızlık ve okul terki nedenlerini; ailenin ekonomik sorunları $(f=26)$, öğrenimine devam eden çocuklarının iş gücünden yararlanmaları $(f=14)$, ailelerin eğitim seviyelerinin düşük olması $(f=9)$, okul ile iletişim kurmada sorun yaşamaları (kişisel nedenler, sosyokültürel nedenler, alan ve statüden kaynaklanan nedenler) $(f=8)$, aile içi sorunları $(f=6)$, ailenin çocuğun geleceği konusunda bir kaygı taşımaması $(f=6)$, eğitime karşı ilgisiz olmaları $(f=5)$ ve ailenin baskıcı tutuma sahip olması $(f=4)$ şeklinde sıralamaktadırlar. verilmiştir:

$\mathrm{Bu}$ konuyla ilgili öğretmenlerin cevapları örnek olarak aşağıda

"Aile kesinlikle \% 80 oranında etkilidir. Ailenin kayıtsız kalması ve özellikle çocuğun ev işlerine, babanın işine destek olması bilinçsiz 
birçok veliyi memnun kılmaktadır. Öğrenci de haliyle daha rahat bir şekilde okuldan kopmaktadır (Yönetici 30)."

"Evet, ailenin öğrenciye ilgisiz kalması, öğrencinin okuyacağına inanmaması, öğrencisini yeterince tanımayıp başka öğrencilerle kıyaslaması, okul ile gerekli iletişimi kurmaması okuldan kopmalarına neden olmaktadır (Yönetici, 10)."

\section{E. Öğrencilerin Devamsızlık ve Okul Terkinde Sosyal Çevrenin}

\section{Etkisi}

Yöneticilerin ve öğretmenlerin, öğrencilerin devamsızlık ve okul terkinde sosyal çevrenin etkilerine ilişkin görüşlerini almak amacıyla “Öğrencilerin devamsızlık ve okul terkinde sosyal çevrenin etkili olduğunu düşünüyor musunuz?" sorusu sorulmuştur. Şekil 5'te öğrencilerin devamsızlık ve okul terkinde sosyal çevrenin etkisine ilişkin oluşturulan temalar ile bu temalar altında yer alan alt temalar arasındaki ilişkiyi ve bu ilişkinin yönünü gösteren bir model oluşturulmuştur.

Şekil 5'te görüldüğü gibi, çalışmaya katılan öğretmen ve okul yöneticilerinden 50'si (\%83,3) öğrencilerin devamsizlık ve okul terkinde sosyal çevrenin etkili olduğunu ifade ederken, $10(\% 16,7)$ katılımcı ise sosyal çevrenin bir etkisinin olmadığını ifade etmektedir. "Evet" yanıtını veren katılımcıların bu konudaki düşünceleri 5 alt temada kodlanmıştır. Öğretmen ve yöneticiler, sosyal çevrenin devamsızlık ve okul terki davranışlarının oluşmasında; sosyal çevrenin özendiriciliği $(f=12)$, olumsuz rol modellerden etkilenme $(f=20)$, oyun mekânlarında vakit geçirmeyi tercih etme (internet kafe, eğlence parkı gibi) $(f=9)$, çevresinde saygınlık kazanma çabasına girme $(f=8)$ ve kültürel etmenlerin (ataerkil veya muhafazakar düşünce yapısına sahip bir çevrede yaşama vb.) $(f=6)$ gibi sosyal çevre kaynaklı faktörlerin rol oynadığını belirtmektedirler. verilmiştir:

$\mathrm{Bu}$ konuyla ilgili öğretmenlerin cevapları örnek olarak aşağıda

"Evet, sosyal çevre etkilidir. Çocuk yaşadığı çevrenin yansıması olarak eğilim ve örnekler hangi yönde ağırlıktaysa ona göre motive olur. Öğrencilere iyi bir model olabilecek sosyal çevrede yetişen çocukların devamsızlık oranı yok denecek kadar az iken, eğitim ve kültür seviyesi düşük olan çevreden gelen çocuklarda devamsızlık oranlarının fazla olduğu açık olarak görülmektedir (Öğretmen, 30)."

"Sosyal çevre her zaman bir öğrenci için cazibe alanıdır. Öğrencinin okulda ve evde yaşadığ her problem öğrenciyi bu alternatif alana itmekte ve yanlış davranışların oluşmasına sebep olmaktadır, buna devamsızlık da dâhildir (Öğretmen, 16)." 


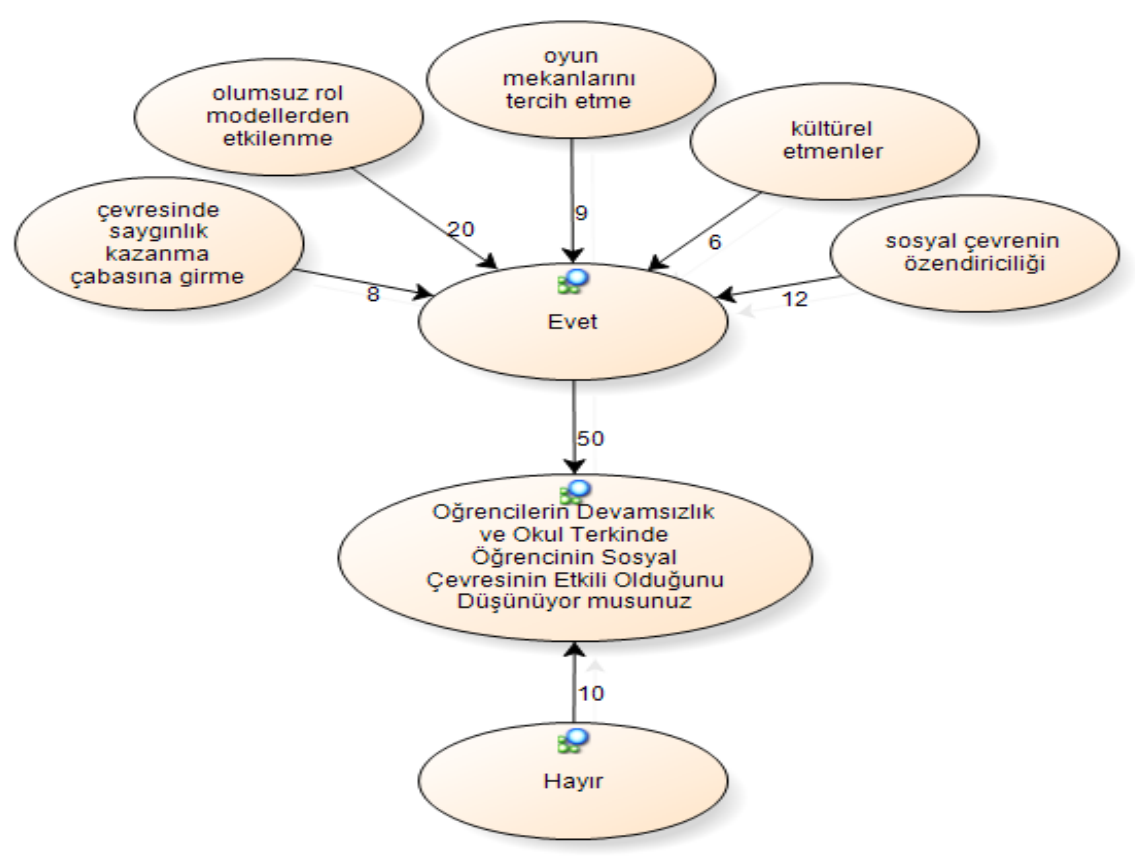

Şekil 5. Yönetici ve Öğretmenlerin, Öğrencilerin Devamsızlık ve Okul Terkinde Sosyal Çevrenin Etkilerine İlişkin Düşüncelerinden Oluşturulan Model

\section{F. Öğrencilerin Devamsızlık ve Okul Terkinde Akademik Başarı Kaygısının Etkisi}

Yöneticilerin ve öğretmenlerin, öğrencilerin devamsızlık ve okul terkinde akademik başarı kaygısının etkilerine ilişkin görüşlerini almak amacıyla "Öğrencilerin devamsızlık ve okul terkinde öğrencinin akademik başarı kaygılarının etkili olduğunu düşünüyor musunuz?" sorusu sorulmuştur. Şekil 6'da öğrencilerin devamsızlık ve okul terkinde akademik başarı kaygısının etkisine ilişkin oluşturulan temalar ile bu temalar altında yer alan alt temalar arasındaki ilişkiyi ve bu ilişkinin yönünü gösteren bir model ortaya konulmuştur. 


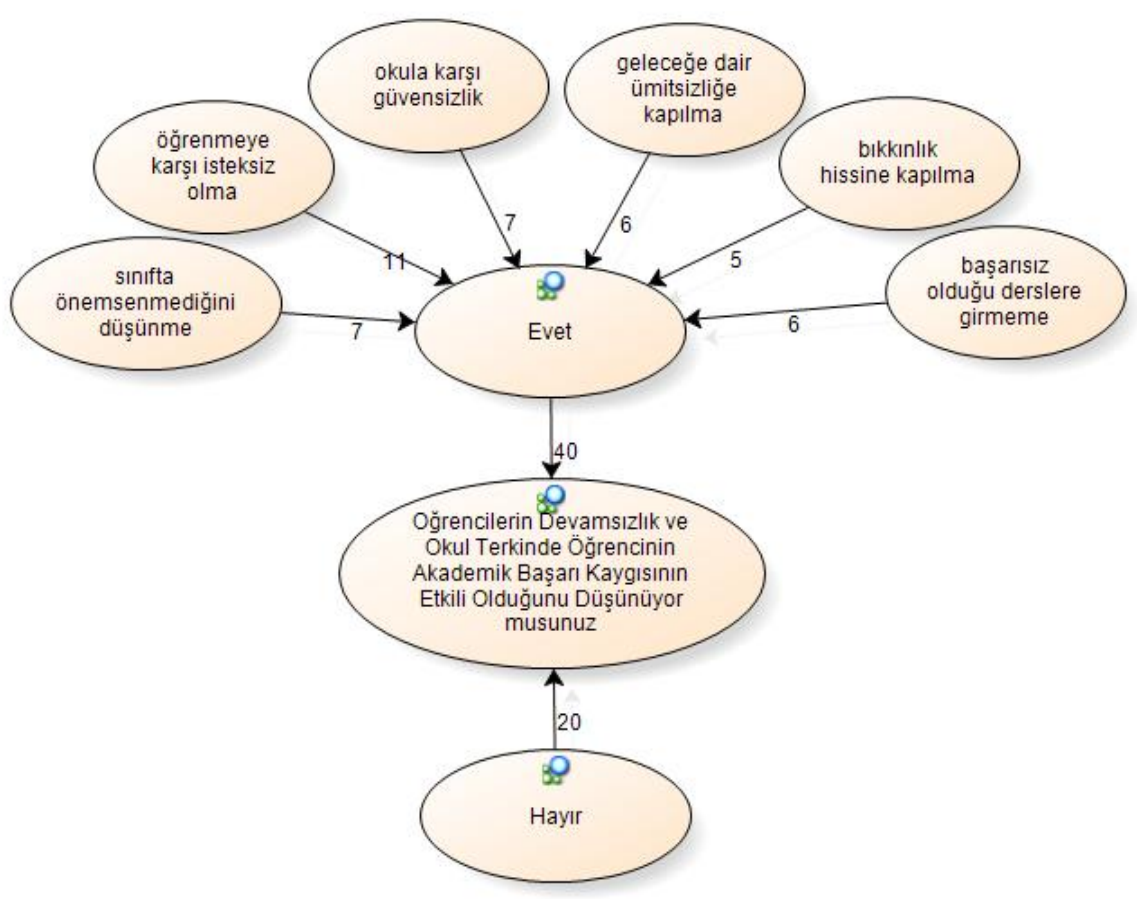

Şekil 6. Yönetici ve Öğretmenlerin, Öğrencilerin Devamsızlık ve Okul Terkinde Akademik Başarı Kaygısının Etkilerine İlişkin Düşüncelerinden Oluşturulan Model

Şekil 6'da görüldügü gibi, çalışma grubundaki 40 (\%66,7) öğretmen ve okul yöneticisi, öğrencilerin devamsızlık ve okul terkinde akademik başarı kaygılarının etkili olduğunu ifade ederken, 20 (\%33,3) öğretmen ve okul yöneticisi ise bunun bir etkisinin olmadığını ifade etmektedir. Akademik başarı kaygısının etkili olduğunu düşünen katılımcıların yanıtları 6 alt temada kodlanmıştır. Öğretmen ve okul yöneticilerine göre akademik başarı kaygısı olan veya bu başarısı düşük düzeyde olan öğrencilerin; öğrenmeye karşı isteksiz olma ( $f=11)$, okula karşı güvensizlik duyma $(f=7)$, sınıfta öğretmen ve öğrenciler tarafından önemsenmediğini düşünme $(f=7)$, geleceğe dair ümitsizliğe kapılma $(f=6)$, başarısız olduğu derslere girmeme $(f=6)$ ve başarısızlık yaşamaktan dolayı bıkkınlık hissine kapılma $(f=5)$ durumlarını yaşadıklarını ve bunun da devamsızlık veya okul terkine neden olduğunu ifade etmektedirler.

Bu konuyla ilgili öğretmenlerin cevapları örnek olarak aşağıda verilmiştir: 
"Kesinlikle okul terklerinin en önemli sebebi derslerdeki başarısızlık ve başaramama kaygısıdır. Başarısız öğrenci gereksiz öğrencidir anlayışının maalesef geçerli olması (Yönetici, 5)."

"Etkilidir, hatta öğrencide aşağıllk kompleksi gibi psikolojik durumlara neden olabilir. Bu durum da öğrencinin kendini daha mutlu hissedeceği farkl bir ortama yönelmesine neden olur (Ö̈̆retmen, 3)."

\section{G. Öğrencilerin Devamsızlık ve Okul Terkini Azaltmaya Yönelik Uygulanan Stratejiler}

Yöneticilerin ve öğretmenlerin, öğrencilerin devamsızlık ve okul terkini azaltmaya yönelik uyguladıkları stratejilere ilişkin görüşlerini almak amacıyla "Öğrencilerin devamsızlık ve okul terkini azaltmaya yönelik uyguladığınız stratejiler nelerdir?" sorusu sorulmuştur. Şekil 7'de yönetici ve öğretmenlerin, öğrencilerin devamsızlık ve okul terkini azaltmaya yönelik uyguladıkları stratejilere ilişkin oluşturulan temalar ile bu temalar altında yer alan alt temalar arasındaki ilişkiyi ve bu ilişkinin yönünü gösteren bir model yer almaktadır.

Şekil 7'de yönetici ve öğretmenlerin, öğrencilerin devamsızlık ve okul terkini azaltmaya yönelik uyguladıkları stratejilere ilişkin görüşleri 15 alt temada kodlandığı görülmektedir. Bu davranışları azaltabilmek için en çok; velilerle etkili iletişim kurma $(f=17)$, velilere yönelik seminerler düzenleme $(f=12)$, okulun fiziki olanaklarını iyileștirme $(f=8)$, öğrenciye başarı hissini tattırma $(f=8)$ ve okuldaki sosyal etkinlikleri artırma $(f=8)$ gibi stratejileri uyguladıklarını ifade etmektedirler. Ayrıca, arkadaş çevresini gözlemleme, öğrenciye sorumluluk yükleme, sorunun kaynağına inme ve aileye ekonomik destek sağlanması için girişimde bulunma gibi stratejileri de uyguladıklarını belirtmişlerdir.

Bu konuyla ilgili öğretmenlerin cevapları örnek olarak aşağıda verilmiştir:

“Öğretmenin, devamsizllk potansiyeli yüksek olan öğrenciye karşı önlem alması gerekir. Söz konusu öğrenciyi okula alıştırmak için yapacağı ilk şey ona sevgisini vermektir. Sinıfta öğrencilere karşı esprili olmalıdır öğretmen. Öğrencinin olumlu davranışları pekiştirilmeli, öğretmen velilerle sürekli iletişim halinde olmalıdır (Öğretmen, 13)."

"En önemlisi arkadaş çevresini oluştururken okul-öğretmen-aile işbirliği içinde olmal, internet kullanırken takip edilmeli, etkin bir denetimin yapıldığı hissettirilmeli, sorun bulunmalı sorun 
bulunduktan sonra sorunu giderme yollarna gidilmeli bu durumda devamsızlık riski ortadan kalkacaktır (Yönetici, 4)."

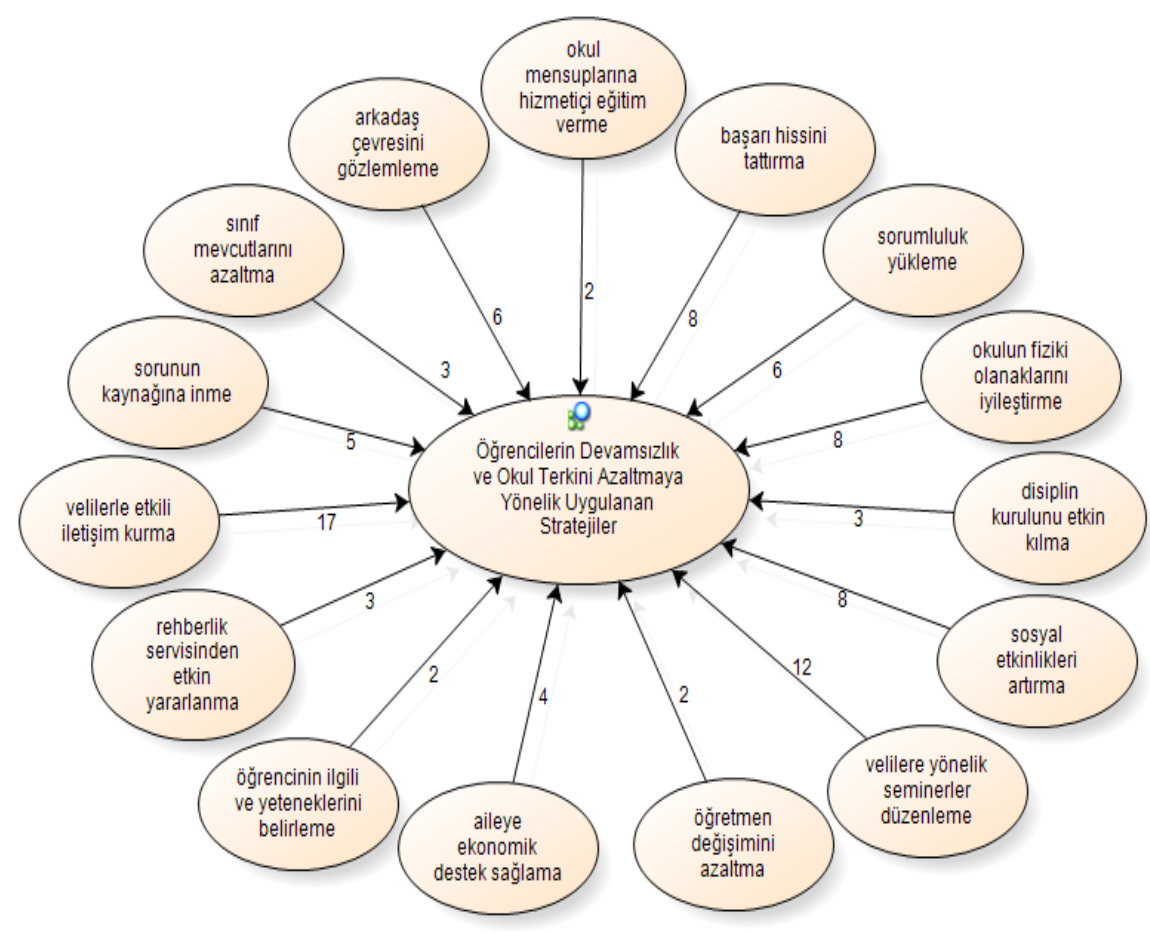

Şekil 7. Yönetici ve Öğretmenlerin, Öğrencilerin Devamsızlık ve Okul Terkini Azaltmaya Yönelik Uygulanan Stratejilere İlişkin Düşüncelerinden Oluşturulan Model

\section{Sonuç, Tartışma ve Öneriler}

Çalışmadan elde edilen bulgular incelendiğinde öğretmen ve yönetici görüşleri 1şığında öğrencilerin okul devamsızlı̆̆ı ve terki davranışlarının kaynağı büyük oranda ailenin çocuklarına karşı duyarlı olamayışları ve bu ailelerin karşılaştıkları ekonomik zorluklar olarak ifade edildiği görülmüştür. Elde edilen bu sonuç, alan yazındaki benzer çalışmaların sonuçlarıyla örtüşmektedir (Burns, 1993; Bülbül, 2012; Diyu, 2001; Özbaş, 2010; Yavuzer, 1996). Öğrencilerle sürekli etkileşim halinde olan ve onları takip eden öğretmen ve idarecilerin bu görüşü aynı zamanda ülkemiz eğitim sisteminde çözümü pek mümkün olamamış bir sorunla da benzeşmektedir. Yapılan program reformları, okul-aile işbirliğini artırma 
çalışmaları gibi eğitimde kaliteyi artırma çabalarına rağmen ailelerle istenilen düzeyde işbirliği bir türlü sağlanamamış, özellikle de okula ilgisi az olan ve devamsızlık yapma eğiliminde olan öğrencilerin aileleri eğitim sürecinde kendilerine yer bulamamış olabilirler. Bu nedenle öğretmen ve yöneticiler de bu desteği ailelerden bulamadıkları için öğrencilerin devamsızlık ve okul terki durumlarının en olası nedeni olarak ailelerini görmektedir. Öte yandan ailelerin ekonomik sıkıntılar çekiyor olması öğrencileri gerek isteyerek gerekse zorunlu olarak iş hayatına sürüklemekte, hem okulu hem iş yaşamını birlikte sürdürmelerini de çoğunlukla imkânsız kılarak okuldan uzaklaşmalarına neden olmaktadır.

Mevcut çalışmada katılımcılara yöneltilen öğrencilerinin devamsızlık ve okul terki eğilimlerini nasıl anladıkları sorusuna en çok derse karşı ilgisizlik, öğrencilerin kurmuş oldukları arkadaşlıklar ve disiplinsiz davranışlar sergilemelerinden anladıklarını belirtmeleri, öğrencilerin okula bağlllıklarının düşük olduğuna işaret edebilir.

$\mathrm{Bu}$ nitel araştırmada katılımcılara yöneltilen devamsızlık ve okul terkine neden olan faktörlerden ailenin, okulun, akademik başarı kaygısının ve sosyal çevrenin ne derece etkilediği sorulmuştur. Öğrencilerin ailelerinin ekonomik sıkıntılarının veya yanlarında çalıştırarak ücretsiz işgücü elde etmelerinin başlıca etmenler olduğu ifade edilebilir. Çalışma grubunda yer alan katılımcıların çalıştıkları yöreler (Güneydoğu Anadolu Bölgesindeki şehir ve kırsal kesimler) göz önüne alınırsa halkın sosyo-ekonomik durumundan dolayı öğrencilerinde okul devamsızlığı ve terki davranışları sergilemeleri beklentisi gerçekleşmiştir (Diyu, 2001). Yine eğitim seviyesi düşük bu coğrafyada ebeveynlerin çocuklarının okula devam etmeleri konusunda yeterli teşviki sağlayamadıkları da düşünülebilir.

Öte yandan, araştırmadan elde edilen bulgulara göre devamsızlık ve okul terkine neden olan faktörlerin başında aile olduğu görülse de diğer faktörler de dikkat çekmektedir. Örneğin, öğretmenlerinden veya okullarından yeterince memnuniyet sağlayamamış öğrencilerde daha sık rastlanan devamsızlık ve okul terki durumları daha önceki çalışmaları da destekler niteliktedir (Reyes ve Jason, 1993; Şimşek, 2011). Bu durum okula devam etmeme gibi davranış sergileyen öğrencilerin algılarının ve beklentilerinin üzerine eğilme ihtiyacı doğurduğu düşünülebilir. Çünkü cazibesi olan ve sunduklarıyla öğrenciler için çekici olan bir okul kurumunu bu tür öğrenciler bırakmak istemeyecekleri öngörülebilir. Örneğin, öğretmen ve yöneticilere göre meslektaşlarının öğrencilerini desteklememeleri, kayıtsız kalmaları ve öğrencilerini yeterince önemsememeleri gibi olumsuz tutumlarından dolayı öğrencilerin memnuniyet düzeyleri azalmakta ve öğrenciler okuldan soğumaya 
başlamaktadır. Buradan çıkan sonuçla okul devamsızlığı ve terkinde eğitimcilerin de önemli bir iz bırakıyor olduğu söylenebilir. Ayrıca okulun eğitsel ve fiziki olanaklarının sınırlı olması da katılımclar tarafından vurgulanmış, öğretim etkinliklerinin çeşitlendirilmesi ve okullarda fiziki iyileştirmelerin gerektiği anlaşılmaktadır.

Diğer taraftan, çalışmaya katılan öğretmen ve yöneticilerin görüşlerine göre başarısız oldukları veya olacakları kaygısından dolayı öğrenciler devamlılık durumlarını aksatmaktadır. Aydın'ın (2006) da belirttiği gibi bu tür öğrencilerin okul devamsızlıkları ve terki yapmaları olasıdır. Çünkü akademik başarı kaygısı yüksek olan öğrenciler öğrenmeye karşı isteksiz olabilmekte, derse girmek istememekte, okula güven duymamakta ve sınıfta başarısızlıklarından dolayı önemsenmediklerini düşünebilmektedir. Bu nedenle geleceklerine dair ümitsizliğe düşüp okula karşı beklentilerini azaltmakta, devamsızlık yapmaları artmakta ve okulu terk etmeye doğru ilerleyebilmektedirler.

Öğrencilerin sosyal çevrelerinin devamsızlık yapmalarına ve okulu bırakmalarına nasıl etki ettiği sorusuna katılımclar genellikle kurulan yanlış arkadaş ilişkilerini ve bu öğrencilerin çevrelerine özenmelerini sebep göstermişlerdir. Özbaş'ın (2010) belirttiği gibi, okulu bırakmış veya okula karşı olumsuz tutumlar benimsemiş, suç işlerine karışma potansiyeli olan kişilerin birbirlerini de etkileyerek kendilerini okuldan uzak tuttukları söylenebilir. Bu noktada ergenliğe de adım atmakta olan öğrencilerin bu tür arkadaşlarına özenip onlar gibi olmaması içten bile değildir. Çarpıcı bir nokta ise, öğretmen ve yöneticiler öğrencilerinin devamsızlık yapmalarına sebep olarak internet kafe ve oyun mekânlarına sıklıkla gitmelerini göstermiştir. Genellikle okuldan kaçma davranışlarıyla öğrenciler okula gelmemekte veya bazı derslere girmemektedirler. Ayrıca bazı katılımcılar muhafazakâr bir toplum baskısı nedeniyle de öğrencilerinin okula devam edemediğini belirtmişlerdir.

Çalışmada, öğretmen ve yöneticilere ayrıca devamsızlık ve okul terkini azaltma yönünde ne tür stratejiler uyguladıkları sorusu da yöneltilmişidir. Verilen yantlar geniş bir yelpazede olsa da onlara göre aldıkları tedbirlerin başında velilerle etkili bir iletişim kurmak ve bu konularda daha duyarlı olmalarını sağlamak için bilgilendirme seminerleri düzenlenmeye çalıştıkları ön plana çıkmıştır. Çalışmanın diğer araştırma sorularına verilen cevaplardan da anlaşılacağı gibi, katılımcılar en çok ailenin sebep olduğu devamsızlık ve okul terki davranışlarının yine ailenin tutum ve davranışlarının değiştirilerek engellenebileceğine inanmaktadırlar. $\mathrm{Bu}$ stratejilerle birlikte, okulların eğitsel altyapısını güçlendirecek iyileştirmelerin yapılması ve okulda sosyal etkinliklerin artırılması için çaba 
sarf ettiklerini belirtmişlerdir. Çalışma grubunda yer alan öğretmen ve yöneticiler her ne kadar öğrenciyi okuldan soğutan nedenler arasında gösterdikleri öğretmen ve yöneticilerin olumsuz yaklaşımlarına dair bir öneride bulunmasalar da öğretmen değişimlerinin azaltılmasiyla devamsızlık ve okul terklerinin azalacağı yönünde görüş belirtenlerin olduğu da görülmüştür.

$\mathrm{Bu}$ çalışmanın ışığında okul yöneticilerinin ve öğretmenlerinin ilköğretimdeki öğrenci devamsızlıkları ve okul terkine ilişkin teşhislerinin, düşüncelerinin, yaklaşımlarının ve önerilerinin neler olduğu araştırılmıştır. Elde edilen bulgulardan çıkarılabilecek bazı sonuçlar mevcuttur. Örneğin, öğretmenlere ve yöneticilere göre bir öğrencinin okula devam etmemesinin birinci sebebi aile kaynaklı sıkıntılar olduğudur. Gerek ekonomik gerekse eğitime karşı ilgisizlik toplumsal birtakım muhafazakâr etkilerle de birleştiğinde velilerin çocuklarına okula teşvik edemedikleri anlaşılmaktadır. Bu durumun düzelmesi için hem okulu bir cazibe merkezi haline getirecek tedbirlerin hem de bu tür ailelerle yakından ilgilenip farkındalıkları artırılmasının sağlanması gerekli görülmektedir. Okulların altyapısının yetersiz veya daha doğru bir ifadeyle bazı öğrencilere hitap etmediği katılımcıların görüşlerinden anlaşılmaktadır. Bu durumun üzerine gitmek için önce eğitim sistemi herkese uygun mu diye sorgulanmalı ve risk altındaki öğrenciler için önlemler ve yol haritaları çizilmelidir. Böylece çalışmaya katılan öğretmen ve yöneticilerin uyguladıklarını belirttikleri bireysel çözüm yollarına profesyonellik katılarak daha başarılı olunabilir. Yine eğitim sistemini topluma sunarken okulu bir zorunluk olduğu için değil, vatandaşların daha iyi bir yaşam sürdürebilmeleri için var olduğu vurgulanmalı, özellikle okul terkine yönelen öğrencilere bu noktaya gelmeden durumları takip edilerek bireye özgü danışmanlık ve rehberlik hizmetleri verilmelidir.

$\mathrm{Bu}$ çalışmada öğretmenler ve yöneticiler gözünden devamsızlık sorunu irdelenmiştir. Bu konuda alan yazına katkı sağlayacak ve öğrencilerle ailelerini de içine alacak benzer nitel çalışmalar konuya daha da genişlik kazandıracaktır. Ayrıca çalışmanın farklı ekonomik ve coğrafik bölgelerde de gerçekleştirilmesi sonuçların genellenebilmesi için veya daha farklı sonuçlara ulaşarak devamsızlık ve okul terki konularının asgari düzeye indirilmesine katkı sağlayabileceğine inanılmaktadır. 
Sosyal Bilimler Dergisi 189

\section{Kaynakça}

ALLIANCE FOR EXCELLENT EDUCATION (2008). The High Cost of High School Dropouts: What the Nation Pays for Inadequate High Schools, (Washington, DC: Author, 2008). (www.all4ed.org adresinden 16 Mart 2014 tarihinde alınmıştır).

AYDIN, İ. (2006). Öğrenciye Uygun Okul Şart. (http://www.radikal.com.tr/haber.php?haberno=183091adresinden 30 Mart 2014 tarihinde alınmıştır).

BAHALI, K. ve TAHİROĞLU, A. Y. (2010). Okul Reddi: Klinik Özellikler, Tanı ve Tedavi. Psikiyatride Güncel Yaklaşımlar, 2(3), 362-383.

BÜLBÜL, T. (2012). Yükseköğretimde Okul terki: Nedenler ve Çözümler. Education \& Science/Egitim ve Bilim, 37(166), 219-235.

BURNS, R.C. (1993). Parents and Schools: From to Parents. Washington: National Education Association.

BÜYÜKÖZTÜRK, Ş. (2007). Sosyal Bilimler İçin Veri Analizi El Kitabı. Ankara: Pegem A Yayıncilik.

CAMPBELL, L.A. (2004). As Strong as the Weakest Link: Urban High School Dropout. High School Journal, 87(2), 16-24.

CASSEL, R. N. (2003). A High School Drop-Out Prevention Program for the at-Risk Sophomore Students. Education, 123(4), 649-658.

CHRISTENSON, S.L., SINCLAIR, M.F., LEHR, C.A. ve HURLEY, C.M. (2000). Promoting Successful School Completion. In K. Minke \& G. Bear (Eds.), Preventing School Problems-Promoting School Success: Strategies and Programs that Work (pp. 377-420). Bethesda, MD: National Association of School Psychologists.

DIYU, X. (2001). Investigation and Discussion on the Problem of Primary and Secondary School Dropouts in Poor Areas. Chinese Education and Society. 33 (5), 49-58.

EASTMAN, G. (1998). Family Involvement in Education. Madison WI: Wisconsin Department of Education.

EĞİTiM REFORMU GİRIşiMI (2009). Eğitimde Eşitlik Politika Analizi ve Öneriler. İstanbul: Sabancı Üniversitesi İstanbul Politikalar Merkezi.

EKIZ, D. (2013). Bilimsel Araştırma Yöntemleri. Ankara: Anı Yayıncılık.

FORTIN, L., MARCOTTE, D., POTVIN, P. ve ROYER, E. (2006). Typology of Students at Risk of Dropping Out of School: Description by Personal, Family and School Factors. European Journal of Psychology of Education, 21(4), 363-383.

HOUSE OF REPRESENTATIVES STANDING COMMITTEE ON EMPLOYMENT (1996). Education and Training Truancy and exclusion from school. 3. AGPS, Canberra. 
KUŞ, E. (2003). Nicel-Nitel Araştırma Teknikleri. Ankara: Anı Yayıncılık.

LOCKHEED, M. E. ve VERSPOOR, A. M. (1991). Improving Primary Education in Developing Countries. Oxford University Press for World Bank.

MAYRING, P. (1996). Einführung in die Qualitative Sozialforschung, Weinheim, Psychologie Verlags Union. (Almanca'dan çevirenler: Adnan Gümüş \& M. Sezai Durgun, 2000, Adana: Baki Kitabevi).

MILES, M. ve HUBERMAN, A. (1994). Qualitative Data Analysis: An Expanded Source Book (2nd Ed.), Thousand Oakes: Sage Publications.

MEB (2009). Devamsızlık ve Okulu Terk Riski Durum Saptaması ve İhtiyaç Analizi Raporu. Ankara.

OKTAY, A. (2007). Okul Öncesi Eğitim ve İlköğretim. İlköğretmen Dergisi, 6, 6-19.

ÖZBAŞ, M. (2010) İlköğretim Okullarında Öğrenci Devamsızlı̆̆ının Nedenleri. Education \& Science/Eğitim ve Bilim, 35(156), 32-44.

REYES, O. ve JASON, L. A. (1993). Pilot Study Examining Factors Associated with Academic Success for Hispanic High School Students. Journal of Youth and Adolescence, 22, 57-71.

ROSSMAN, G. ve RALLIS, S. F. (1998). Learning in the Feld: An Introduction to Qualitative Research. California: Sage.

ŞİMŞEK, H. ve ŞAHİN S. (2012). İlköğretim İkinci Kademe Öğrencilerinde Okulu Bırakma Eğilimi ve Nedenleri (Şanlıurfa İli Örneği). Abant İzzet Baysal Üniversitesi Ĕ̆itim Fakültesi Dergisi, 12(2), 41-72.

ŞİMŞEK, H. (2010). Güneydoğu Anadolu Bölgesindeki Lise Öğrencilerinin Sosyal Bütünleşme Düzeyleri ve Gelecek Beklentileri. 109K300 Nolu Proje Raporu, TÜBİTAK: Ankara.

ŞİMŞEK, H. ve KATITAŞ, S. (2014) İlköğretim İkinci Kademe Öğrencilerinde Okula Yabancılaşmanın Çeşitli Değişkenler Açısından İncelenmesi (Şanlıurfa İli Örneği). Ahi Evran Üniversitesi Kırşehir Ĕ̆itim Fakültesi Dergisi (KEFAD), 15(1), 81-99.

TUNÇ, İ. A. (2009). Kız Çocuklarının Okula Gitmeme Nedenleri Van İli Örneği. Yüzüncü Yal Üniversitesi Eğitim Fakültesi Dergisi, VI(I), 237269.

TUTAR, H. (2002). Türk Cumhuriyetleri ve Akraba Topluluklarmdan Gelen Öğrencilerin Başarısızlık Nedenleri. Yayımlanmamış yüksek lisans tezi, Kırıkkale Üniversitesi Sosyal Bilimler Enstitüsü Sosyoloji Anabilim Dalı, Kırıkkale.

UYSAL, A. ve ŞAHİN, Y. (2007, 5-7 Eylül). Ortaöğretimde Okulu Bırakma Olgusunu Tetikleyen Yapısal/Çevresel Faktörler, 16. Eğitim Bilimleri Kongresi, Osmangazi Üniversitesi, Tokat-Türkiye. 
WALTERS, G. D. (1992). Foundations of Criminal Science. New York: Praeger. www.hurriyet.com.tr. (27 Ocak 2001). 1 Milyon 635 Çocuk Sokakta Çalışıyor. (http://hurarsiv.hurriyet.com.tr/goster/ShowNew.aspx?id=-220338 adresinden30 Mart 2014 tarihinde alınmıştır).

YAVUZER, H. (1996). Çocuk ve Suç (8. Baskı). İstanbul: Remzi Kitabevi.

YILDIRM, A. ve ŞİMŞEK, H. (2008). Sosyal bilimlerde nitel araştırma yöntemleri. Ankara: Seçkin Yayıncılık.

YILDIZ, M. ve KULA, Ş. K. (2011). Elazığ İlindeki İlköğretim İkinci Kademe Öğrencilerinin Devamsızlık Sebeplerinin İncelenmesi. Fırat Üniversitesi Fen Bilimleri Dergisi, 23(2), 133-140. 
C. AKÜZÜM, T. YAVAŞ, Ç. TAN, M. B. UÇAR $\mid 192$ 